\title{
RESPONSE OF GROUND NUT (ARACHIS HYPOGAEA, L.) TO DIFFERENT SOWING DATES AND SEEDING RATES IN NEWLY RECLAIMED LAND.
}

Ekram, A. Megawer, A.A. A. Mekdad and Heba, M. El Damy

\author{
Agronomy Department, Faculty of Agriculture, Fayoum University, \\ Egypt
}

\begin{abstract}
Two field trials were carried out in the Farm of the Faculty of Agriculture, Demo, Fayoum University, Egypt, during the two successive summer seasons 2016 and 2017, to study the effect of sowing dates and seeding rates on yield and its components and quality of peanuts in newly reclaimed land. The experimental design was split-plots design in RCBD with three replicates, where sowing date $\left(1^{\text {st }}, 20^{\text {th }}\right.$ April, $10^{\text {th }}$ and $30^{\text {th }}$ May) were assigned to the main plots, and seeding rate at 30, 40 and $50 \mathrm{~kg} / \mathrm{fad}$. (one feddan $=4200 \mathrm{~m}^{2}$ ) were distributed in the sub-plots. The obtained results could be summarized as follows.

Sowing on April $1^{\text {st }}$ gave significantly highest on all studied traits at harvest like plant height, number of branches, number of pods per plant and weight of pod per feddan (1.87 and $1.92 \mathrm{tlfed}$.), seed yield per feddan (1.06 and 1.15 tlfed.) and oil yield per feddan (512.61 and $573.81 \mathrm{~kg} / \mathrm{fed}$.) in both seasons. Decreasing the seeding rate from 50 to $30 \mathrm{kglfed}$ produced significantly for all studied traits at harvest like plant height, number of branches, weight of pods (41.85 and $44.27 \mathrm{~g}$ ), weight of seed and oil \%. On the other hand, increasing the seeding rate from 30 to $50 \mathrm{~kg} / f e d$ produced significantly the highest values of yield in terms of pod (1.89 and $1.87 \mathrm{tlfed}$.), seed (1.01 and 1.04 tonlfed) and oil (476.20 and $494.00 \mathrm{~kg} / \mathrm{fed})$ in both season respectively.

There were highly significant effects due to the interaction between sowing dates and seeding rates on number of branches in the first season, weight of pods per plant and pod yield per feddan in the second one. The highest values of seed yield (1.21 and 1.34 tons) and oil yield (584.44 and $664.75 \mathrm{~kg}$ ) per feddan in both seasons, respectively were obtained by sowing on $1^{\text {st }}$ April and seeding rate of $50 \mathrm{~kg} / \mathrm{fed}$. The data revealed that, positive and highly significant $(\mathrm{P} \leq 0.01)$ correlations were obtained between oil yield $\mathrm{kg}$ fed $^{-1}$ and each of seed yield $\mathrm{t} \mathrm{fed}^{-1}\left(\mathrm{r}=0.993^{* *}\right.$ and $\left.0.995^{* *}\right)$ and pod yield $\mathrm{t}$ $\mathrm{fed}^{-1}\left(\mathrm{r}=0.888^{* *}\right.$ and $\left.0.873^{* *}\right)$ in $1^{\text {st }}$ and $2^{\text {nd }}$ seasons, respectively. According to Stepwise results in data in Table 6 clarified that two traits i.e. seed yield and oil $(\%)$ in both seasons were significantly $(\mathrm{P} \leq 0.001)$ contributed to variation in oil yield $\mathrm{kg}$ per feddan.
\end{abstract}

Keywords: Peanut, sowing dates, seeding rates, correlations, Stepwise, yield, yield components and yield quality.

Fayoum J. Agric. Res. \& Dev., Vol. 33, No.2, July, 2019 


\section{INTRODUCTION}

The ground nut is a valuable food and oilseed crop. It is commonly called as the king of vegetable oilseeds crops or poor man's nut. The ground nut (also called peanut, earth nut, monkey nut, goober nut, manila nut, pinder and panda nut) is a native of South American leguminous oil seed (Hammons, 1982). It belongs to family Leguminosae. It was first found in Brazil or Peru as early as 950 B.C. (Higgins, 1951). A peanut was probably brought to West Africa from Brazil in the $16^{\text {th }}$ century and then to the African East coast and to India. Groundnut appeared to have originated in South America i.e., NorthWest of Brazil and the secondary center of its cultivation is in Africa and then spread to other parts of the world. India is one of producer and ranks second in groundnut production after China.

Ground nut is a rich source of oil, which supplies about 500 calories per $100 \mathrm{~g}$ which is higher than all vegetable proteins. Groundnut is also a rich source of minerals and vitamins like vitamin-B, vitamin-E (tocopherol) Arya et al. (2016).

Ground nut is grown on large scale in almost all the tropical and subtropical countries of the world. Ground nut is the third important oils seed crop of the world in production after soybean and cotton (FAO, 1988). The important ground nut growing countries are India, China, Nigeria, Sudan and USA. Groundnut is grown on 22.2 million ha area in more than 100 countries in the world with a total production of $34.5 \mathrm{MT}$ and average productivity of 1.55 tonnes per ha. Asia accounts for 55.2 percent of the global area and 66.7 percent of the global production of the crop compared to 40.3 percent of the area and 25.6 percent of the production in Africa. It is worth to note and document that Egypt is suffering dramatically from great shortage in edible oils needed for nutritional consumption. Although the total local production from plant oils is about $340.000 \mathrm{t}$ in $2015 / 2016$, the consumption is about $2.690 .000 \mathrm{t}$ in the same year. This indicated that there is a great gap (87.4\%) between production and consumption, which has created importation to fulfill the requirements of local market (FAO, 2016).

Peanut crop cultivated area at Egypt decreased from 147778 feddan in 2013 season to be 143022 feddan which yielded 1.37 tonnes per feddan in 2015 season. (Agriculture Directorates of Governorates $\mathbf{2 0 1 5}^{\mathbf{1}}$ )

Peanut crop cultivated area at Fayoum province decreased from 597 feddan in 2011 season to be 45 feddan in 2016 season. Groundnut is popular among the farmers because it provides greater and assured returns compare to most of competing crops.

The yield potential of peanut is genetically determined and depends on limiting factors such as soil and climatic conditions, plant arrangement and incidence of pests or diseases. Among the factors affecting the productivity of

\section{${ }^{1}$ Agriculture Directorates of Governorates 2015}

Fayoum J. Agric. Res. \& Dev., Vol. 33, No.2, July, 2019 
RESPONSE OF GROUND NUT (ARACHIS HYPOGAEA, L.) TO......... 63 a culture, plant density affects directly the components production. For the peanut crop, plant density may vary depending on cultivar, sowing date, fertilization and cultivation region.

Planting date plays an important role on the peanut yield, the variations of planting dates may interact with differences in climatic conditions in particular; temperature degree, photoperiod and relative humidity which affect the physiological processes by performance and behavior of genotype, and when climatic conditions are not suitable for need of one of yield components, it would negatively affect the seed yield. Williams (2000) suggested that physiological processes are the best tools to explain the variation in peanut yield, which are the pod filling period and the rate of pod establishment.

Seeding rates which determine the population density and consequently the area available to individual plant has been shown to affect crop growth and yield performance (Ntare, 1990). High density cropping in groundnut is known to reduce weed competition for space and growth resources. It was reported by Dalley et al. (2004) to exhibit greater light interception compared to low density cropping. The adoption of high density cropping has primarily been driven by the potential for higher yields obtained from such systems compared to low density production systems. A study by Jaaffar and Gardner (1988) showed that higher seeding rates gave greater ground cover, leaf area indices, canopy light interception, crop growth rates and ultimately higher pod yields when compared to conventional low density groundnut crop.

So the goal of this investigation is, therefore, to study the effect of suitable sowing dates and seeding rates, and their interaction for better growth and yield of groundnut crop.

\section{MATERIALS AND METHODS}

Two field trials were carried out in the Farm of the Faculty of Agriculture, Demo (2917` N; 3053` E), Fayoum University, Egypt, during the two successive summer seasons 2016 and 2017, to study the effect of sowing dates and seeding rates on growth, yield, yield components and quality of peanuts Arachis hypogaea L.

\section{Soil characteristics:}

Particle size distribution and some chemical properties of the experimental soil, were determined according to Wilde $\boldsymbol{e t}$ al. (1985), and presented in Table (1).

\section{Treatments:}

Peanut variety: Giza (6) was obtained from Food Legume Research Section, Field Crop Research Institute, Agricultural Research Center, Giza, Egypt.

Sowing dates, (S) were: $1^{\text {st }}$ April, April $20^{\text {th }}, 10^{\text {th }}$ May and May $30^{\text {th }}$.

Seeding rates (R) were: 30,40 and $50 \mathrm{~kg} / \mathrm{fed}$. (one feddan $=4200 \mathrm{~m}^{2}$ ).

Fayoum J. Agric. Res. \& Dev., Vol. 33, No.2, July, 2019 


\section{Experimental design:}

In both seasons, a split-plots design in RCBD with three replicates was used with sowing dates as main plots and seeding rates were randomly butted in sub-plots. The sub-plot area was $10.5 \mathrm{~m}^{2}$ and consisting of five ridges of 3.5 $\mathrm{m}$ length and $60 \mathrm{~cm}$ in width.

\section{The cultural practices:}

The normal treatments of growing peanut plants were practiced and sowing was preceded by faba bean in 2016 season and sugar beet in 2017 season. Inoculated seeds just before planting with the specific Rhizobium bacteria inoculants. The assessed nitrogen fertilizer, as ammonium sulfate $(20.6 \% \mathrm{~N})$ at $40 \mathrm{~kg} \mathrm{fad}^{-1}$ was added as in three equal doses at 15, 30 and 45 days after planting. Phosphorus fertilizer, as calcium superphosphate $(15.5 \%$ $\mathrm{P}_{2} \mathrm{O}_{5}$ ) at $250 \mathrm{~kg} \mathrm{fad}^{-1}$ rate, potassium fertilizer as potassium sulfate, $48 \% \mathrm{~K}_{2} \mathrm{O}$ at $24 \mathrm{~kg} \mathrm{k}_{2} \mathrm{O} \mathrm{fad}^{-1}$ rate and organic fertilizer at $20 \mathrm{~m}^{3} \mathrm{fad}^{-1}$ rate were incorporated into the soil surface during seed bed preparation. Surface irrigation was adopted as recommended.

The maximum, minimum and mean daily temperature in centigrade and relative humidity, in percent, at monthly from April to November in 2016 and 2017 seasons, at Fayoum province as taken from the metrological department are shown in Table (2).

Table (1): Particle size distribution and some chemical properties of the experimental soil in 2016 and 2017 seasons.

\begin{tabular}{|c|c|c|c|c|}
\hline \multicolumn{3}{|c|}{ Season } & 2016 & 2017 \\
\hline \multicolumn{3}{|c|}{ Sand $\%$} & 66.5 & 76.1 \\
\hline \multicolumn{3}{|c|}{ Silt\% } & 12.4 & 10.8 \\
\hline \multicolumn{3}{|c|}{ Clay\% } & 21.1 & 13.1 \\
\hline \multicolumn{3}{|c|}{ Textural class } & Sandy clay Loam & Sandy Loam \\
\hline \multicolumn{3}{|c|}{$\mathrm{CaCO} 3 \%$} & 7.10 & 5.20 \\
\hline \multirow{4}{*}{ Cations } & \multirow{7}{*}{ meqL $L^{-1}$} & $\mathrm{Na}^{+}$ & 69.80 & 65.70 \\
\hline & & $\mathrm{K}^{+}$ & 2.82 & 1.40 \\
\hline & & $\mathrm{Mg}^{+2}$ & 25.00 & 11.18 \\
\hline & & $\mathrm{Ca}^{+2}$ & 30.88 & 60.62 \\
\hline \multirow{3}{*}{ Anions } & & $\mathrm{SO}_{4}^{-2}$ & 28.60 & 33.40 \\
\hline & & $\mathrm{CL}^{-}$ & 92.40 & 94.50 \\
\hline & & $\mathrm{HCO}^{-}$ & 7.50 & 11.0 \\
\hline \multicolumn{3}{|c|}{ Organic Matter \% } & 1.47 & 0.70 \\
\hline \multicolumn{3}{|c|}{$\mathrm{ECe}, \mathrm{dSm}^{-1}$ at $25^{\circ} \mathrm{C}$} & 2.89 & 2.33 \\
\hline \multicolumn{3}{|c|}{$\mathrm{pH}$ at $25 \mathrm{C}^{\circ}$} & 8.63 & 8.87 \\
\hline \multirow{4}{*}{\multicolumn{2}{|c|}{$\begin{array}{l}\text { Micronutrients } \\
\quad(\mathrm{ppm})\end{array}$}} & $\mathrm{Fe}$ & 6.86 & 4.29 \\
\hline & & $\mathrm{Mn}$ & 4.21 & 3.57 \\
\hline & & $\mathrm{Cu}$ & 1.46 & 0.69 \\
\hline & & $\mathrm{Zn}$ & 1.10 & 0.29 \\
\hline
\end{tabular}

Fayoum J. Agric. Res. \& Dev., Vol. 33, No.2, July, 2019 
RESPONSE OF GROUND NUT (ARACHIS HYPOGAEA, L.) TO

Table (2): The monthly averages of temperature and relative humidity during the two growing seasons at Fayoum Governorate.

\begin{tabular}{|c|c|c|c|c|c|c|c|c|}
\hline & \multicolumn{4}{|c|}{2016} & \multicolumn{4}{|c|}{2017} \\
\hline & $\begin{array}{l}\text { Min. } \\
\text { Tem. }\end{array}$ & $\begin{array}{l}\text { Max. } \\
\text { Tem. }\end{array}$ & $\begin{array}{l}\text { Aveg. } \\
\text { Tem. }\end{array}$ & $\begin{array}{c}\text { Relative } \\
\text { humidity }\end{array}$ & $\begin{array}{l}\text { Min. } \\
\text { Tem. }\end{array}$ & $\begin{array}{l}\text { Max. } \\
\text { Tem. }\end{array}$ & $\begin{array}{l}\text { Aveg. } \\
\text { Tem. }\end{array}$ & $\begin{array}{c}\text { Relative } \\
\text { humidity }\end{array}$ \\
\hline April & 17.0 & 36.1 & 26.5 & 35.0 & 15.6 & 31.2 & 23.4 & 34.0 \\
\hline May & 19.8 & 36.0 & 27.9 & 32.0 & 19.5 & 36.5 & 28.0 & 30.0 \\
\hline June & 24.3 & 40.3 & 32.3 & 34.0 & 19.3 & 36.4 & 27.8 & 30.0 \\
\hline July & 24.7 & 40.6 & 32.7 & 38.0 & 25.9 & 40.3 & 33.1 & 36.0 \\
\hline Aug. & 24.5 & 39.9 & 32.2 & 36.0 & 26.0 & 40.4 & 33.2 & 36.0 \\
\hline Sept. & 23.6 & 38.2 & 30.9 & 37.0 & 23.8 & 38.3 & 31.0 & 36.0 \\
\hline Oct. & 21.6 & 33.0 & 27.3 & 39.0 & 18.6 & 32.3 & 25.5 & 38.0 \\
\hline Nov. & 15.6 & 28.1 & 21.9 & 42.0 & 13.4 & 26.2 & 19.8 & 41.0 \\
\hline
\end{tabular}

\section{Data recorded:}

\section{A-Plant characteristics at harvest:}

At harvest, the following data were recorded as an average of 5 plants taken randomly from each plot of three replications to determine the following characters:

1- Plant height $(\mathrm{cm})$

2- Number of branches per plant

3- Number of pods per plant

4- Weight of pods per plant $(\mathrm{g})$

5- Number of seeds per plant

6- Weight of seed per plant (g)

B- Yield characteristics and quality:

The whole peanut plants of the two middle ridges for each sub-plot were used for determination of:

1- Pods yield per fed. (ton per fed.) was estimated by weighing the pods in two ridges of each experimental unit plot in tons, then transformed into feddan.

2- Seed yield per fed. (ton per fed.) was estimated by weighing the seeds in two ridges of each experimental unit plot in tons, then transformed into feddan.

3- Seed oil content \%: was determined by using the modified soxhelt apparatus and petroleum ether as a solvent according to A. O. A. C. (1990).

4- Oil yield per fed. (ton per fed.). It was calculated by multiplying seed yield by oil percentage.

\section{Statistical analysis:}

All obtained data were statistically analyzed according to the technique of analysis of variance (ANOVA) for the spilt- plot design as outlined by Gomez and Gomez (1984), using MSTAT statistical package (MSTAT- C). Least Significant Difference (LSD, at 5\% level of probability) was used to test the differences between treatments mean. The data of oil yield and its

Fayoum J. Agric. Res. \& Dev., Vol. 33, No.2, July, 2019 
Ekram, A. Megawer, et al.,

components of the study were analyzed by two statistical procedures; simple correlation coefficient and stepwise regression was used in order to determine the most important variables contributed to oil yield variability (Draper and Smith, 1981). For this purpose computer software SPSS (version 21) was used.

Table3. Effect of sowing dates, seeding rates and their interaction on plant height, number of branches, pod and seed, weight of pod and seed of groundnut in 2016 and 2017 seasons

\begin{tabular}{|c|c|c|c|c|c|c|c|c|c|c|c|c|c|}
\hline \multicolumn{2}{|c|}{ Treatments } & \multicolumn{2}{|c|}{$\begin{array}{c}\text { Plant height } \\
(\mathrm{cm})\end{array}$} & \multicolumn{2}{|c|}{$\begin{array}{c}\text { Number of } \\
\text { branches }\end{array}$} & \multicolumn{2}{|c|}{$\begin{array}{c}\text { Number of pods } \\
\text { per plant }\end{array}$} & \multicolumn{2}{|c|}{$\begin{array}{c}\text { Weight of pods } \\
\text { per plant }\end{array}$} & \multicolumn{2}{|c|}{$\begin{array}{c}\text { Number of } \\
\text { seeds per plant }\end{array}$} & \multicolumn{2}{|c|}{$\begin{array}{c}\text { Weight of seeds } \\
\text { per plant }\end{array}$} \\
\hline $\begin{array}{c}\text { Sowing } \\
\text { dates }(\mathbf{S})\end{array}$ & $\begin{array}{c}\text { Seeding } \\
\text { rates }(\mathbf{R}) \\
\end{array}$ & 2016 & 2017 & 2016 & 2017 & 2016 & 2017 & 2016 & 2017 & 2016 & 2017 & 2016 & 2017 \\
\hline \multirow{4}{*}{$1^{\text {st }}$ April } & $30 \mathrm{~kg} / \mathrm{fed}$ & 62.52 & 65.93 & 17.42 & 18.53 & 32.67 & 33.69 & 49.78 & 51.34 & 60.52 & 54.26 & 33.51 & 34.46 \\
\hline & $40 \mathrm{~kg} / \mathrm{fed}$ & 60.47 & 60.64 & 16.58 & 17.69 & 30.93 & 31.76 & 48.48 & 49.90 & 59.40 & 60.94 & 32.24 & 32.89 \\
\hline & $50 \mathrm{~kg} / \mathrm{fed}$ & 58.20 & 57.88 & 15.96 & 15.90 & 29.63 & 30.31 & 46.64 & 49.26 & 57.22 & 59.91 & 30.48 & 31.25 \\
\hline & Mean & 60.40 & 61.49 & 16.65 & 17.37 & 31.08 & 31.92 & 48.30 & 50.17 & 59.05 & 58.37 & 32.08 & 32.87 \\
\hline \multirow{4}{*}{$2^{\text {th }}$ April } & $30 \mathrm{~kg} / \mathrm{fed}$ & 56.10 & 58.77 & 15.45 & 16.71 & 29.48 & 30.11 & 45.63 & 48.44 & 55.88 & 58.22 & 29.61 & 30.12 \\
\hline & $40 \mathrm{~kg} / \mathrm{fed}$ & \begin{tabular}{|l|}
54.59 \\
\end{tabular} & 55.32 & 14.76 & 15.44 & 28.47 & 28.22 & 43.41 & 45.49 & 53.40 & 56.56 & 28.59 & 28.86 \\
\hline & $50 \mathrm{~kg} / \mathrm{fed}$ & 52.46 & 50.20 & 14.34 & 14.08 & 27.11 & 27.17 & 40.69 & 42.61 & 51.33 & 55.27 & 27.33 & 27.12 \\
\hline & Mean & \begin{tabular}{|l|}
54.38 \\
\end{tabular} & 54.77 & 14.85 & 15.41 & 28.35 & 28.50 & 43.24 & 45.51 & 53.54 & 56.68 & 28.51 & 28.70 \\
\hline \multirow{4}{*}{$10^{\text {th }}$ May } & $30 \mathrm{~kg} / \mathrm{fed}$ & \begin{tabular}{|l}
49.74 \\
\end{tabular} & 50.04 & 13.76 & 13.69 & 25.88 & 26.37 & 38.80 & \begin{tabular}{|l}
41.89 \\
\end{tabular} & 49.46 & 52.38 & 26.14 & 25.31 \\
\hline & $40 \mathrm{~kg} / \mathrm{fed}$ & 48.06 & 45.76 & 13.19 & 12.76 & 24.88 & 25.28 & 37.09 & 39.79 & 46.60 & 49.96 & 25.01 & 24.24 \\
\hline & $50 \mathrm{~kg} / \mathrm{fed}$ & 45.92 & 42.58 & 12.77 & 12.17 & 23.97 & 24.08 & 35.19 & 36.38 & 44.87 & 47.22 & 23.86 & 22.81 \\
\hline & Mean & 47.91 & 46.13 & 13.24 & 12.87 & 24.91 & 25.24 & 37.03 & 39.35 & 46.98 & 49.85 & 25.00 & 24.12 \\
\hline \multirow{4}{*}{$30^{\text {th }}$ May } & $30 \mathrm{~kg} / \mathrm{fed}$ & 44.30 & 40.32 & 12.19 & 11.85 & 22.74 & 22.92 & 33.18 & 35.39 & 43.40 & 43.15 & 22.88 & 22.17 \\
\hline & $40 \mathrm{~kg} / \mathrm{fed}$ & \begin{tabular}{|l|}
41.99 \\
\end{tabular} & 37.29 & 11.37 & 11.35 & 21.35 & 21.51 & 30.42 & 33.90 & 41.77 & 40.15 & 20.44 & 21.25 \\
\hline & $50 \mathrm{~kg} / \mathrm{fed}$ & 39.43 & 34.63 & 10.92 & 10.99 & 20.40 & 20.88 & 29.45 & 31.48 & 38.53 & 38.27 & 19.48 & 20.21 \\
\hline & Mean & \begin{tabular}{|l|}
41.91 \\
\end{tabular} & 37.42 & 11.50 & 11.40 & 21.50 & 21.77 & 31.02 & 33.59 & 41.24 & 40.52 & 20.93 & 21.21 \\
\hline \multirow{3}{*}{$\begin{array}{c}\text { Mean of } \\
\text { (R) }\end{array}$} & $30 \mathrm{~kg} / \mathrm{fed}$ & 53.17 & 53.77 & 14.71 & 15.20 & 27.69 & 28.27 & 41.85 & 44.27 & 52.32 & 52.00 & 28.04 & 28.01 \\
\hline & $40 \mathrm{~kg} / \mathrm{fed}$ & 51.28 & 49.76 & 13.98 & 14.31 & 26.41 & 26.69 & 39.85 & 42.27 & 50.29 & 51.90 & 26.57 & 26.81 \\
\hline & $50 \mathrm{~kg} / \mathrm{fed}$ & 49.00 & 46.33 & 13.50 & 13.29 & 25.28 & 25.61 & 37.99 & 39.93 & 47.99 & 50.17 & 25.29 & 25.35 \\
\hline \multirow{3}{*}{$\operatorname{LSD}_{(5 \%)}$} & S & $2.60 * *$ & $2.80 * *$ & $0.50^{\text {**: }}$ & 0.80 ** & $0.50^{* *}$ & $1.12 * *$ & $0.64 * *$ & $3.92 * *$ & $1.71^{* *}$ & 4.85 ** & 1.21 *** & $1.03 * *$ \\
\hline & $\mathbf{R}$ & $0.54 * *$ & $0.93 * *$ & $0.30^{* * 3}$ & $0.30^{* *}$ & $0.30^{* *}$ & 0.41 ** & $0.60 * *$ & $0.81^{* *}$ & $0.70^{* *}$ & ns & $0.51 * *$ & 0.50 ** \\
\hline & $\mathbf{S} * \mathbf{R}$ & ns & $\mathrm{ns}$ & $0.90^{*}$ & ns & ns & ns & ns & $4.85^{*}$ & ns & $\mathrm{ns}$ & ns & ns \\
\hline
\end{tabular}

$* ; P<0.05, * * ; P<0.01$ and ns; non-significant

Fayoum J. Agric. Res. \& Dev., Vol. 33, No.2, July, 2019 
Table 4. Effect of sowing dates, seeding rates and their interaction on oil \%, pod, seed and oil yield of groundnut in 2016 and 2017 seasons.

\begin{tabular}{|c|c|c|c|c|c|c|c|c|c|}
\hline \multicolumn{2}{|c|}{ Treatments } & \multicolumn{2}{|c|}{ Oil percentage } & \multicolumn{2}{|c|}{$\begin{array}{c}\text { Pods yield } \\
\text { (ton/fed) }\end{array}$} & \multicolumn{2}{|c|}{$\begin{array}{c}\text { Seed yield } \\
\text { (ton/fed) }\end{array}$} & \multicolumn{2}{|c|}{ Oil yield (kg/fed) } \\
\hline $\begin{array}{c}\text { Sowing dates } \\
\text { (S) }\end{array}$ & $\begin{array}{l}\text { Seeding } \\
\text { rates }(\mathbf{R})\end{array}$ & 2016 & 2017 & 2016 & 2017 & 2016 & 2017 & 2016 & 2017 \\
\hline \multirow{4}{*}{$1^{\text {st }}$ April } & $30 \mathrm{~kg} / \mathrm{fed}$ & 48.05 & 50.63 & 1.67 & 1.65 & 0.93 & 0.94 & 446.04 & 474.40 \\
\hline & $40 \mathrm{~kg} / \mathrm{fed}$ & 49.10 & 49.92 & 1.89 & 1.95 & 1.03 & 1.17 & 507.36 & 582.27 \\
\hline & $50 \mathrm{~kg} / \mathrm{fed}$ & 48.45 & 49.47 & 2.04 & 2.16 & 1.21 & 1.34 & 584.44 & 664.75 \\
\hline & Mean & 48.53 & 50.01 & 1.87 & 1.92 & 1.06 & 1.15 & 512.61 & 573.81 \\
\hline \multirow{4}{*}{$2^{\text {th }}$ April } & $30 \mathrm{~kg} / \mathrm{fed}$ & 48.47 & 48.86 & 1.65 & 1.54 & 0.86 & 0.86 & 417.79 & 421.00 \\
\hline & $40 \mathrm{~kg} / \mathrm{fed}$ & 48.06 & 48.38 & 1.81 & 1.79 & 0.95 & 0.96 & 456.79 & 463.28 \\
\hline & $50 \mathrm{~kg} / \mathrm{fed}$ & 47.35 & 48.10 & 1.95 & 1.95 & 1.11 & 1.07 & 524.77 & 516.92 \\
\hline & Mean & 47.96 & 48.44 & 1.80 & 1.76 & 0.97 & 0.96 & 466.45 & 467.07 \\
\hline \multirow{4}{*}{$10^{\text {th }}$ May } & $30 \mathrm{~kg} / \mathrm{fed}$ & 47.27 & 47.56 & 1.54 & 1.45 & 0.79 & 0.76 & 372.62 & 363.35 \\
\hline & $40 \mathrm{~kg} / \mathrm{fed}$ & 46.94 & 46.86 & 1.74 & 1.62 & 0.85 & 0.82 & 399.00 & 383.93 \\
\hline & $50 \mathrm{~kg} / \mathrm{fed}$ & 46.50 & 46.74 & 1.82 & 1.72 & 0.92 & 0.95 & 425.47 & 444.30 \\
\hline & Mean & 46.90 & 47.05 & 1.70 & 1.60 & 0.85 & 0.84 & 399.03 & 397.19 \\
\hline \multirow{4}{*}{$30^{\text {th }}$ May } & $30 \mathrm{~kg} / \mathrm{fed}$ & 46.12 & 46.41 & 1.42 & 1.45 & 0.65 & 0.64 & 301.78 & 295.60 \\
\hline & $40 \mathrm{~kg} / \mathrm{fed}$ & 45.98 & 45.85 & 1.57 & 1.56 & 0.74 & 0.72 & 342.38 & 331.84 \\
\hline & $50 \mathrm{~kg} / \mathrm{fed}$ & 45.61 & 45.36 & 1.74 & 1.68 & 0.81 & 0.77 & 370.10 & 350.03 \\
\hline & Mean & 45.90 & 45.87 & 1.58 & 1.56 & 0.74 & 0.71 & 338.09 & 325.82 \\
\hline \multirow{3}{*}{ Mean of (R) } & $30 \mathrm{~kg} / \mathrm{fed}$ & 47.48 & 48.36 & 1.57 & 1.52 & 0.81 & 0.80 & 384.56 & 388.59 \\
\hline & $40 \mathrm{~kg} / \mathrm{fed}$ & 47.52 & 47.75 & 1.75 & 1.73 & 0.89 & 0.92 & 426.38 & 440.33 \\
\hline & $50 \mathrm{~kg} / \mathrm{fed}$ & 46.98 & 47.42 & 1.89 & 1.88 & 1.01 & 1.04 & 476.20 & 494.00 \\
\hline \multirow{3}{*}{$\operatorname{LSD}_{(5 \%)}$} & $\mathbf{S}$ & $0.84 * *$ & $0.71 * *$ & $0.10 * *$ & $0.10^{* * *}$ & $0.03 * *$ & $0.10^{* * *}$ & $17.06^{* * *}$ & $39.64 * *$ \\
\hline & $\mathbf{R}$ & ns & $0.20 * *$ & $0.03 * *$ & $0.03 * *$ & $0.03 * *$ & $0.03 * *$ & $13.78 * *$ & $15.64 * *$ \\
\hline & $\mathbf{S} * \mathbf{R}$ & ns & ns & ns & $0.10 *$ & $0.10 * *$ & $0.10^{* * *}$ & $27.56^{* *} *$ & $31.28 * *$ \\
\hline
\end{tabular}

*; $P<0.05,{ }^{* *} ; P<0.01$ and ns; non-significant.

\section{RESULTS AND DISCUSSION}

\section{A-Effect of sowing dates:}

The data in Table $(3 \& 4)$ presented the effect of sowing dates on plant height, number of branches, number of pods, weight of pods, number of seeds, weight of seeds per plant and oil percentage, as well as yields in terms of pods, seeds and oil per feddan in 2016 and 2017 seasons. Sowing dates exhibited highly significant differences in formers traits on in both seasons. According to LSD test early sowing date on $1^{\text {st }}$ April produced significantly the maximum values of plant height $(60.40$ and $61.49 \mathrm{~cm})$, number of branches (15.396 and 15.90), number of pods (31.08 and 31.92), weight of pods (48.30 and $50.17 \mathrm{~g}$ ), number of seeds (59.05 and 58.37), weight of seeds per plant (32.08 and 32.87) and oil \% (48.53 and 50.01) as well as, pods yield (1.87 and 1.92), seed yield (1.06 and 1.15) and oil yield (512.61 and 573.81) than the other sowing dates in both seasons respectively. On the other hand, in 2016 and 2017 seasons delay sowing date on $30^{\text {th }}$ May significantly produced the minimum values for the formers traits. The superiority of early sowing dates

Fayoum J. Agric. Res. \& Dev., Vol. 33, No.2, July, 2019 
Ekram, A. Megawer, et al.,

might have been due to most favorable climatic conditions throughout the growth period compared to other sowing dates. The reduction in oil yield per feddan at late sowing in both seasons was expected since seed number and weight per plant and seed yield per feddan well as, percentage of oil decreased at late sowing as mentioned before. The previous results agree with those reported by many investigators among then Abouziena et al. (2013), Maamoun and Abd El Gawad (2013), Sarkees (2015) and Shendage et al. (2018).

\section{B- Effect of seeding rates:}

During the two seasons of experimentation, seeding rates had a highly significant effect on plant height, number of branches and pods, weight of pods and seeds as well as pod, seed and oil yield. In 2016 season seeding rates had a highly significant effect on number of seeds per plant and in 2017 season on oil percentage. The results in Table $(3 \& 4)$ indicated that plant height, number of branches and pods, weight of pods and seeds traits decreased from 53.17 to $49.00,14.71$ to $13.50,27.69$ to $25.28,41.85$ to 37.99 and 28.04 to 25.29 in 2016 season and from 53.77 to $46.33,15.20$ to 13.29 , 28.27 to $25.61,44.27$ to 39.93 and 28.01 to 25.35 in 2017 season with increased rate of seeding from 30 to $50 \mathrm{~kg} / \mathrm{fed}$ respectively. On the other hand, pod, seed and oil yield traits decreased from 1.89 to $1.57,1.01$ to 0.81 and 476.20 to 384.56 in the first season and from 1.88 to $1.52,1.04$ to 0.80 and 494.00 to 388.59 in the second season with decreasing seeding rates from 50to $30 \mathrm{~kg} / \mathrm{fed}$ respectively. The increase in oil yield with increasing plant density was primarily attributed to differences in the amount of photosynthetically active radiation (PAR) intercepted, which was evident during both vegetative growth as well as, seed yield and oil percentage development. It is worth to mention here that increasing seeding rates up to $50 \mathrm{~kg} / \mathrm{fed}$. caused a significant increase in seed yield per feddan. This indicating that the increase in plant number could be easily counter balanced the depression in number of branches, total pods, weight of pods per plant, number of seeds per plant as well as seed yield per plant. The previous results agree with those reported by many investigators among then Bell et al. (1987), Giayetto et al. (1998), Dapaah et al. (2014), Gabisa et al. (2017) and Zhao et al. (2017).

\section{Interactions Effect:}

Regarding the interaction effect between sowing dates and seeding rates. The results clearly showed a significant effect on seed and oil yield per feddan in both season as well as, number branches per plant in the first season, pods weight per plant and pod yield per feddan in the second season. The highest values of seed yield (1.21 and 1.34 tons) and oil yield (584.44 and $664.75 \mathrm{~kg}$ ) per feddan in both seasons, respectively were obtained by sowing on $1^{\text {st }}$ April and seeding rate of $50 \mathrm{~kg} / \mathrm{fed}$.

Fayoum J. Agric. Res. \& Dev., Vol. 33, No.2, July, 2019 
Yield analysis study

Correlation coefficient: The correlation coefficients in Table 5 between oil yield $\mathrm{kg} \mathrm{fed}^{-1}$ and each of number of pod and seed, weight of pod and seed plant $^{-1} \mathrm{~g}$, pod and seed yield $\mathrm{t} \mathrm{fed}^{-1}$ and oil $\%$ were computed in order to throw light on the relationship of effectual traits interest. The data revealed that, positive and highly significant $(\mathrm{P} \leq 0.01)$ correlations were obtained between oil yield $\mathrm{kg} \mathrm{fed}^{-1}$ and each of seed yield $\mathrm{t} \mathrm{fed}^{-1}\left(\mathrm{r}=0.993^{* *}\right.$ and $\left.0.995^{* *}\right)$ and pod yield $\mathrm{t} \mathrm{fed}^{-1}\left(\mathrm{r}=0.888^{* *}\right.$ and $\left.0.873^{* *}\right)$ in $1^{\mathrm{st}}$ and $2^{\mathrm{nd}}$ seasons, respectively. According to Stepwise results in data in Table 6 clarified that two traits i.e. seed yield and oil $(\%)$ in both seasons were significantly $(\mathrm{P} \leq 0.001)$ contributed to variation in oil yield $\mathrm{kg}$ per feddan.

Table 5. A matrix of simple correlation coefficient between oil yield and other important traits estimated in 2016 and 2017 season.

\begin{tabular}{|c|c|c|c|c|c|c|c|c|c|c|c|c|c|c|c|c|}
\hline \multirow[t]{2}{*}{ Character } & \multicolumn{2}{|c|}{$\begin{array}{l}\text { Number of } \\
\text { pod plant }^{-1}\end{array}$} & \multicolumn{2}{|c|}{$\begin{array}{c}\text { Weight of } \\
\text { pod plant }^{-1}(\mathrm{~g})\end{array}$} & \multicolumn{2}{|c|}{$\begin{array}{l}\text { Number of } \\
\text { Seed plan }\end{array}$} & \multicolumn{2}{|c|}{$\begin{array}{l}\text { Weight of } \\
\text { Seed } \mathbf{p}^{-1}(\mathrm{~g})\end{array}$} & \multicolumn{2}{|c|}{$\begin{array}{c}\text { Pod yield } \\
\left(\mathrm{t} \mathrm{fed}^{-1}\right)\end{array}$} & \multicolumn{2}{|c|}{$\begin{array}{c}\text { Seed yield } \\
\left(t \text { fed }^{-1}\right)\end{array}$} & \multicolumn{2}{|c|}{$\begin{array}{l}\text { Oil } \\
(\%)\end{array}$} & \multicolumn{2}{|c|}{$\begin{array}{l}\text { Oil yield } \\
\left(\mathbf{k g ~ f e d ~}^{-1}\right)\end{array}$} \\
\hline & 2016 & 2017 & 2016 & 2017 & 2016 & 2017 & 2016 & 2017 & 2016 & 2017 & 2016 & 2017 & 2016 & 2017 & 2016 & 2017 \\
\hline Number of pod $\mathrm{p}^{-1}$ & 1 & 1 & $.983^{* *}$ & $.869 * *$ & $.973 * *$ & $.799 * *$ & $.971^{* *}$ & $.926 * *$ & $.399 * *$ & $.421 * *$ & $.619^{* *}$ & $.614^{* *}$ & $.784 * *$ & $.962 * *$ & $.672 * *$ & $.685^{* *}$ \\
\hline Weight of pod $p^{-1}(g)$ & & & 1 & 1 & $.987 * *$ & $.820 * *$ & $.985^{* * *}$ & $.870 * *$ & $.411 * *$ & $.426^{* * *}$ & $.628 * *$ & $.610 * *$ & $.790 * *$ & $.839 * *$ & $.682 * *$ & $.666 * *$ \\
\hline Number of Seed $\mathrm{p}^{-1}$ & & & & & 1 & 1 & $.987 * *$ & $.751 * *$ & $.392 * *$ & $.495^{* *}$ & $.610^{* *}$ & $.670 * *$ & $.774 * *$ & $.790^{* *}$ & $.664^{* *}$ & $.711 * *$ \\
\hline Weight of Seed $\mathrm{p}^{-1}(\mathrm{~g})$ & & & & & & & 1 & 1 & $.363 * *$ & $.433^{* *}$ & $.574 * *$ & $.655^{* *}$ & $.753 * *$ & $.958 * *$ & $.630 * *$ & $.723 * *$ \\
\hline Seed yield $\left(\mathrm{t} \mathrm{fed}^{-1}\right)$ & & & & & & & & & & & 1 & 1 & $.575 * *$ & $.642 * *$ & $.993 * *$ & $.995 * *$ \\
\hline Oil (\%) & & & & & & & & & & & & & 1 & 1 & $.667 * *$ & $.716 * *$ \\
\hline Oil yield $\left(\mathrm{t} \mathrm{fed}^{-1}\right)$ & & & & & & & & & & & & & & & 1 & 1 \\
\hline
\end{tabular}

Table 6. Correlation coefficient ( $r)$, coefficient of determination $\left(\mathbf{R}^{2}\right)$ and standard error of the estimates (SEE) for predicting oil yield ( $\mathrm{kg} / \mathrm{fed}$ ) in 2016 and 2017 seasons.

\begin{tabular}{|c|c|c|c|c|c|}
\hline Season & $\mathbf{R}$ & $\mathbf{R}^{\mathbf{2}}$ & SEE & Sig. & Fitted equation \\
\hline 2016 & 1.00 & 1.00 & 1.45 & $* * *$ & Oil yield $=-428.13+474.34$ seed yield +9.05 oil \\
\hline 2017 & 1.000 & 1.000 & 2.31 & $* * *$ & Oil yield $=-413.25+485.98$ seed yield +8.54 oil \\
\hline
\end{tabular}

\section{Conclusion}

Data showed that under newly reclaimed land condition it could be recommended to apply the early sowing date on $1^{\text {th }}$ April combined with rate of $50 \mathrm{~kg}$ per feddan to accomplish acceptable profit yield of peanuts pods, seed and oil yield as well.

\section{REFERENCES}

A.O.A.C. (1990). Official methods of analysis. Association of Official Analytical ChemistsInternational. $15^{\text {th }}$ Ed. AOAC-Int., Arlington, VA.

Abouziena, H. F.; M.S.A. Abd El Wahed; M.A.T. Eldabaa and E.R. ElDesoki (2013). Effect of sowing date and reduced herbicides rate with additives on peanut (Arachis Hypogaea L.) productivit y and

Fayoum J. Agric. Res. \& Dev., Vol. 33, No.2, July, 2019 
Ekram, A. Megawer, et al., associated weeds. Journal of Applied Sciences Research, 9(3): 2176-2187.

Arya1, S. S.; A. R. Salve and S. Chauhan (2016). Peanuts as functional food: a review. Journal of Food Science Technology. 53 (1):3141.

Bell, M. J; R. C. Muchow and G. L. Wilson (1987). The Effect of plant population on peanuts (Arachis hypogaea) in a monsoonal tropical environment. Field Crops Research, 17: 91-107

Dalley, C. B.; J. J. Kells. and K. A. Renner (2004). Effect of glyphosate application timing and row spacing on weed growth in corn (Zea mays) and soybean (Glycine max). Weed Technology. 18:177-182.

Dapaah, H. K.; I. Mohammed and R. T. Awuah (2014). Growth and yield performance of groundnuts (Arachis hypogaea L.) in response to plant density. International Journal of Plant and Soil Science 3(9): 1069-1082.

Draper, N.R. and H. Smith (1981). Applied regression analysis.2nd edition, Wiley series in probability and mathematical statistics, John Wiley \& Sons. N.Y., pp. 709.

FAO (Food and Agriculture Organization of the United Nations), (1988). FAOSTAT: World Crop Production data.

FAO (Food and Agriculture Organization of the United Nations), (2016). FAOSTAT: World Crop Production data.

Gabisa, M.; T. Tana and E. Urage (2017). Effect of planting density on yield components and yield of groundnut (Arachis hypogaea L.) varieties at Abeya, Borena Zone Southern Ethiopia. International Journal of Scientific Engineering and Applied Scienc e, 3(3):1-18.

Giayetto, O; G. A. Cerioni and W. E. Asnal (1998). Effect of sowing spacing on vegetative growth, dry matter production, and peanut pod yield. Peanut Science. 25:86-92.

Gomez, K. A and A. A. Gomez (1984). Statistical Procedures for Agriculture Research. $2^{\text {nd }}$ ed. John Wiley and Sons. New York, USA. 680pp.

Hammons, R. O. (1982). Origin and early history of the pea nut. In pea nut science and Technology, ed. H.E. Pattee and C.T. young, pp.-1-20.

Higgins, B. B. (1951). Origin and early history of the pea nut. The pea nut the Unpredictable legume. Washington: National Fertilizer Association.

Jaaffar, Z. and F. P. Gardner (1988). Canopy development, yield and market quality in peanut as affected by genotype and planting pattern. Crop Science. 28:299-305.

Maamoun, Howaida. A. and A. M. Abd El Gawad (2013). Effect of Salicylic acid, Biofertilization and Sowing Dates on Peanut

Fayoum J. Agric. Res. \& Dev., Vol. 33, No.2, July, 2019 
(Arachis hypogaea L.) Yield under Semi-arid Conditions. Egypt. J. Agron. Vol. 35(1): 37- 64.

Ntare, B. R. (1990). Intercropping morphologically different cowpeas with pearl millet in a short season environment in the Sahel. Experimental Agriculture. 26: 4-48.

Sarkees, N. A. (2015). Effect of sowing dates on development, seed yield and quality of some peanut (Arachis hypogaea L.) genotypes. Jordan Journal of Agricultural Sciences, 11, (2): 367- 380.

Shendage, R. C.; A. B. Mohite and R. K. Sathe (2018). Effect of sowing times and varieties on growth and yield of summer groundnut (Arachis hypogaea L.). Journal of Pharmacognosy and Phytochemistry. 7(1): 720-722.

Wilde, S. A; R. B. Corey; J. G. Lyer and G. K. Voigt (1985). Soil and plant analysis for tree culture. $3^{\text {rd }}$ edition. Oxford and IBM Publishers, New Delhi, India. 93-106.

Williams, J. H. (2000). The implications and applications of resource capture concepts to crop improvement by plant-breeding. Agric. For. Meteorol. 104: 49-58.

Zhao, C.; C. Shao; Z. Yang; Y. Wang; X. Zhang; M. Wang and Jr. M. E. McGiffen (2017). Effects of planting density on pod development and yield of peanuts under the pattern of precision planted peanuts. Legume Research, 40 (5): 901-905.

$$
\begin{aligned}
& \text { إستجابة الفول السودانى للاختلاف فى مواعيد الزراعة ومعدلات التقاوى فى الأراضى الجديدة } \\
& \text { إكر ام على مجاور و على عبدالله على مقداد و هبة مددوح عبدالو احد. } \\
& \text { قسم الدحاصيل ـ كلية الزراعة ـ جامعة الفيوم- الفيوم- مصر. }
\end{aligned}
$$

أقيمت تجربتان حقليتان بمزرعة كلية الزراعة ، بمنطقة دمو ، جامعة الفيوم ، مصر ، خلال

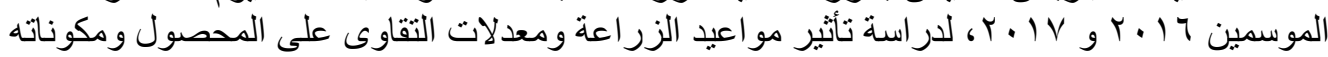

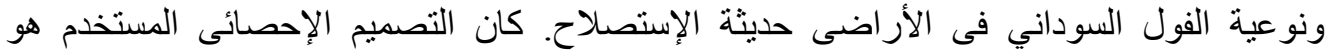

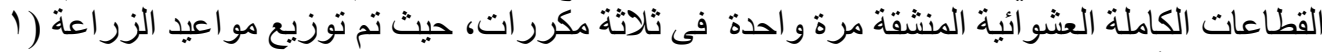

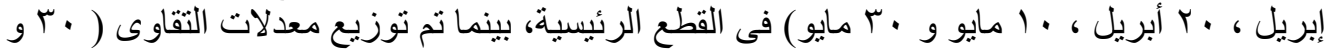

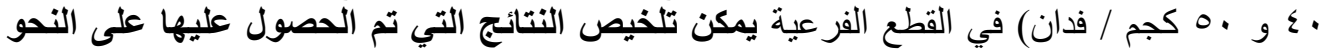

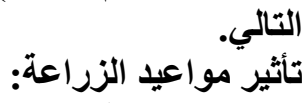

كان لمواعيد الزراعة تأثير معنوي كبير على جميع الصفات الزيل الزراعية قبد الدراسة في كلا

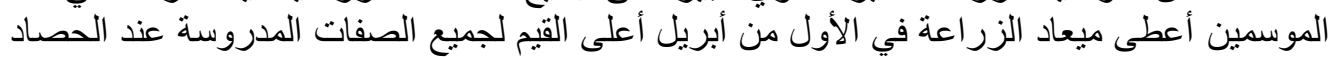

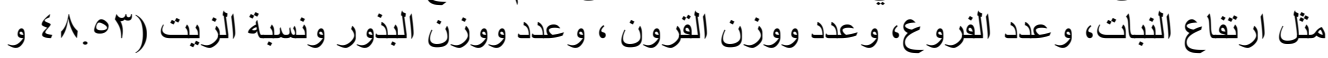

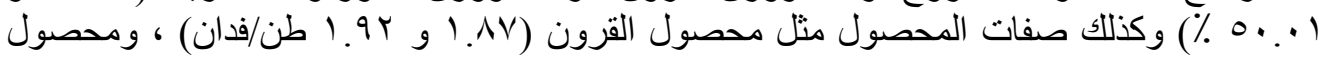

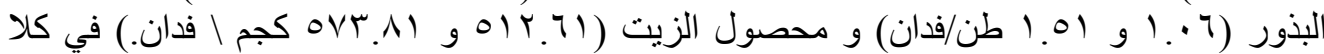

Fayoum J. Agric. Res. \& Dev., Vol. 33, No.2, July, 2019 


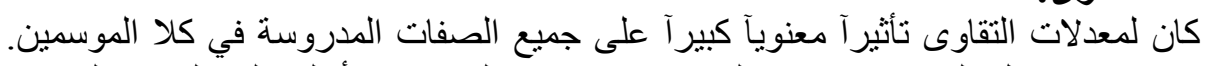

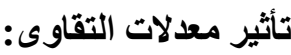

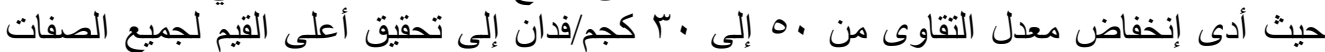

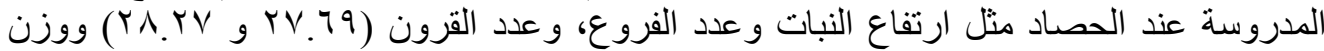

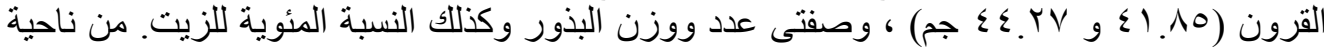

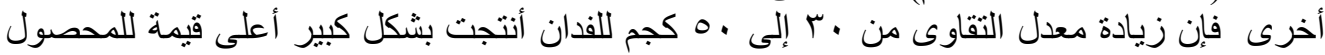

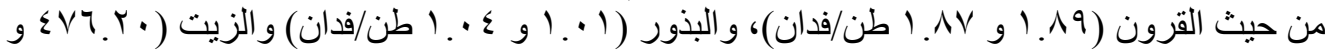

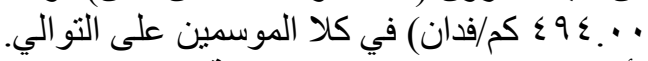

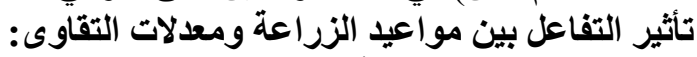

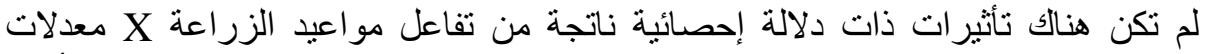

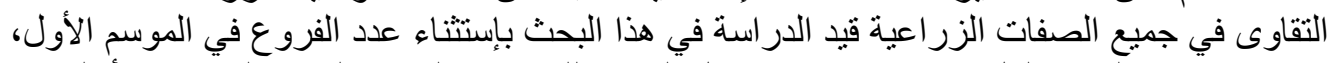

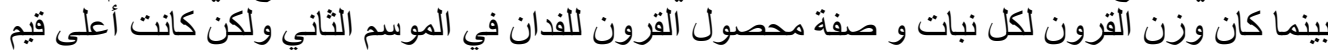

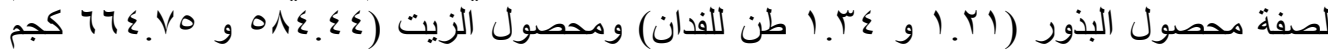

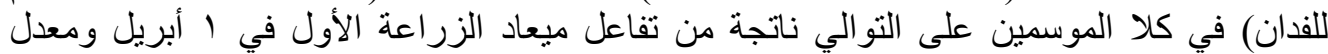

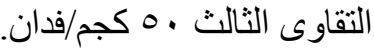

